\title{
Bail-In Regulation and Stock Market Reaction
}

\author{
Franco Fiordelisi \\ University of Essex, United Kingdom \\ Federica Minnucci \\ Consob, Italy \\ Daniele Previati \\ University of Roma Tre, Italy \\ Ornella Ricci \\ University of Roma Tre, Italy
}

\begin{abstract}
In response to the global financial turmoil and sovereign debt crisis, the European Union has introduced a new bail-in resolution mechanism based on the shared burden of losses between shareholders, debt-holders, and depositors. By focusing on the abnormal stock price reactions to bail-in policy announcements, this paper shows that investors perceive the new bail-in regime as a credible tool to decrease government interventions, reduce the too-big-to-fail problem, and increase market discipline in the European banking industry.
\end{abstract}

JEL classification: $\mathrm{G} 21, \mathrm{G} 28$

Keywords: Bail-in, banking crises, event study 


\section{Introduction}

The Eurozone crisis has exposed the lack of a common approach to crisis management and resolution in banking (Caprio and Honohan, 2015). The European Union (EU) followed a radical re-regulation process, including the implementation of a single resolution mechanism (SRM) whose key feature is the bail-in rule. Under this regulation, banking losses are absorbed by shareholders, debt-holders, and depositors over 100 thousand Euro, following a creditor hierarchy principle.

Although the bail-in regulation is a keystone for European banking, only few papers explore SRM and the benefits of a bail-in compared to a bailout (Papanikolaou, 2018; Avgouleas and Goodhart, 2015) using simulation approaches (Benczur et al., 2017) and investigating the role of bank business models. This paper focuses on the market reaction to the bail-in introduction to assess whether investors perceive this tool as a valuable resource to achieve the two primary purposes set by regulators: to minimize the destabilizing effect of banking crises on public finances and enhance market discipline. Three research hypotheses were developed to test a large set of regulatory announcements for European listed banks.

$H_{1}$ ) Investors reduce expectations about future government interventions (bailouts), with a consequent decrease in stock prices.

According to the too-big-to-fail (TBTF) literature (Mattana et al., 2015), the new resolution should severely reduce the probability of a state intervention for large institutions, which were more likely to receive government support in case of financial distress. However, it is also possible that investors are doubtful about the restriction of government interventions for large banking institutions and believe that these banks will be supported despite the new regulation (Schoenmaker, 2014). This leads to the second hypothesis: 
$\mathrm{H}_{2}$ ) The reaction of larger banks is stronger and more relevant with respect to other banks.

Avgouleas and Goodhart (2015) indicate that the bail-in mechanism should incentivize

creditors to resume a monitoring function and consequently restore market discipline. However, at our knowledge, there is no empirical evidence on this issue. Consistently with the market discipline view, the following hypothesis was tested:

$\mathrm{H}_{3}$ ) Bail-in enhances market discipline with stronger reaction for banks that have received state aid in the past and/or show weaker financial conditions.

\section{Data and methodology}

All regulatory announcements dealing with the introduction of the bail-in mechanism from the European Commission's (EC) preliminary plans to the formal adoption of the Bank Recovery and Resolution Directive (BRRD) were collected ${ }^{1}$. Stock returns data were collected from Datastream and bank balance-sheet information from BankScope and Bankfocus.

Abnormal returns (ARs) were calculated as the difference between the observed and expected returns, obtained through the application of a standard market model with a broad reference index (MSCI Europe Index) and a 252-day estimation period, which ends 20 days before each announcement. Cumulative abnormal returns (CARs) were estimated over different short event windows [i.e., $(-1,0),(-1,1),(-1,3)$, and $(-3,3)$ ] (Fiordelisi et al., 2014). There were no other events of potential interest to investors in European banking (i.e., monetary policy interventions).

\footnotetext{
${ }^{1}$ Specifically, we analyze the following announcements: 1) Commission sets out its plans for a new EU framework for crisis management in the financial sector (20 October 2010); 2) Commission seeks views on possible EU framework to deal with future bank failures (06 January 2011); 3) New crisis management measures to avoid future bank bail-outs (06 June 2012); 4) Commission proposes Single Resolution Mechanism for the Banking Union (10 July 2013); 5) The European Parliament adopts the Bank Recovery and Resolution Directive (5 April 2014); 6) The Bank Recovery and Resolution Directive (BRRD) applies in all Member States (01 January 2015); and 7) Single Resolution Mechanism to come into effect for the Banking Union (31 December 2015)
} 
The following model was used to understand the main drivers of CARs (over different event windows $\left.t_{1}-t_{2}\right)$ :

$$
\begin{aligned}
\operatorname{CAR}_{i, e}^{t 1, t 2}=\alpha & +\beta_{1} \text { Euro }_{i, t}+\beta_{2} \text { Size }_{i, t}+\beta_{3} \text { Aid }_{i, t}+\beta_{4} \operatorname{Int}_{i, t}+\beta_{5} \operatorname{Cir}_{i, t}+\beta_{6} \operatorname{Cap}_{i, t} \\
& +\beta_{7} \operatorname{Rwa}_{i, t}+\varepsilon_{i, t}
\end{aligned}
$$

Euro is a dummy taking the value of 1 for banks in the euro area, and 0 otherwise. Bank size (Size) is the natural logarithm of total assets; government aids (Aid) is a dummy taking the value of 1 for banks receiving financial support during the global financial crisis and 0 otherwise; Intb is the liquidity position on the interbank market measured by the ratio between amounts due and loans to banks; Cir is the level of efficiency calculated as the ratio of overhead to operating income; Cap is the ratio of total regulatory capital to risk-weighted assets; and Rwa is the riskweighted assets ratio.

\section{Results and discussion}

The event study results (mean values of CARs and $p$-values) are presented in Table 1. Considering all policy announcements, ARs are generally negative and statistically significant, thereby supporting the first hypothesis, $H_{1}$.

There is no significant evidence for the announcement on October 20, 2010, probably due to the absence of a clear definition of the resolution mechanism. Conversely, there was a statistically significant negative reaction on January 6, 2011, when regulators introduced the concept of creditors bearing losses for the first time. The subsequent interim announcements in 2012 and 2013 were not associated with significant reactions, whereas there were some notable results for the formal adoption on April 15, 2014. Overall, these results are consistent with Schäfer et al. (2016), giving further support to $H_{1}$ that investors believed the bail-in mechanism will reduce the probability of state aid to banks. 
The second-stage regression model (Table 2) is consistent with the results. The focus was only on the dates with significant market reactions, January 6, 2011 and April 15, 2014, including a dummy (Ann) taking the value of 1 for the formal adoption of the BRRD.

The coefficient for Euro is negative and statistically significant for three out of four event windows, consistent with a more effective application of the bail-in tool for euro area countries. The coefficient for Size is negative and statistically significant for three out of four event windows. Consistent with $H_{2}$, larger banks are expected to be more negatively impacted by the introduction of bail-in regulation as a tool to severe the linkage between systemic banking crises and public interventions.

The coefficient for Aid is negative and statistically significant for three out of four event windows. In accordance with $H_{3}$, banks that have already received public support register a stronger unfavorable reaction concerning their competitors. As regards liquidity, the coefficient for Intb is negative and statistically significant for two event windows, signaling a higher risk for banks with a relevant imbalance in their funding strategy. With regard to riskiness, the coefficient for $R w a$ is always negative and statistically significant. Overall, the results provide strong empirical support for the hypothesis $\left(H_{3}\right)$. Finally, the coefficient for Ann (i.e. a dummy taking the value of 1 in the case of a formal adoption, and zero otherwise) is positive and significant, which confirms a more negative reaction for the previous announcement that incorporated higher surprise content (January 6, 2011).

\section{Conclusion}

This paper analyzes stock market reactions to policy announcements introducing the new bail-in tool based on the shared burden of losses between shareholders, debt-holders, and depositors. Findings from the event study analysis are consistent with the expectation that the 
bail-in tool can reduce state aid to banks; however, our findings advance Schäfer et al. (2016) for at least three reasons: First, the analysis includes preliminary announcement dates, for which it is reasonable to expect a stronger surprise effect. Second, a larger sample was used, including listed banks operating outside the euro area. Third, the adjustment suggested by Kolari and Pynnönen (2010) was adopted to correct the significance of CARs for potential cross-correlation.

The second-stage regression model provided two main results. First, the larger banks were more sensitive to the bail-in introduction, consistent with the idea that their probability to receive state support was higher before the imposition of the new regulation. Second, a stronger (negative) market reaction was found for banks that had already received state aids in the past; their funding was more dependent on the interbank market and presented a higher level of risk.

Overall, the market reaction assessment revealed that investors considered the bail-in introduction to be a credible instrument to contain the TBTF problem, reduce state interventions in banking crises, and promote market discipline. 


\section{Table 1. Event study analysis}

This table illustrates the descriptive statistics of CARs estimated over the main EC press releases relative to the bank crisis management. ARs are obtained using a standard market model with a 252-day estimation period. CARs in bold are those that remain statistically significant considering the adjustment suggested by Kolari and Pynnönen (2010). Data are collected from Datastream.

\begin{tabular}{|c|c|c|}
\hline All dates & CAR & P-value \\
\hline$(-1,0)$ & -0.0081 & 0.0251 \\
\hline$(-1,1)$ & -0.0096 & 0.0237 \\
\hline$(-1,3)$ & -0.0101 & 0.0459 \\
\hline$(-3,3)$ & -0.0098 & 0.1284 \\
\hline $\begin{array}{l}\qquad 20 / 10 / 2010 \\
\text { EC sets out its plans for a new EU framework for crisis management }\end{array}$ & CAR & P-value \\
\hline$(-1,0)$ & 0.0051 & 0.4712 \\
\hline$(-1,1)$ & 0.0037 & 0.6684 \\
\hline$(-1,3)$ & 0.0050 & 0.6980 \\
\hline$(-3,3)$ & 0.0054 & 0.6565 \\
\hline $\begin{array}{c}06 / 01 / 2011 \\
\text { EC launches a consultation on technical details }\end{array}$ & CAR & P-value \\
\hline$(-1,0)$ & -0.0110 & 0.1038 \\
\hline$(-1,1)$ & -0.0165 & 0.0683 \\
\hline$(-1,3)$ & -0.0226 & 0.0590 \\
\hline$(-3,3)$ & -0.0280 & 0.0663 \\
\hline $\begin{array}{c}06 / 06 / 2012 \\
\text { EC sets new crisis management measures }\end{array}$ & CAR & P-value \\
\hline$(-1,0)$ & -0.0040 & 0.6881 \\
\hline$(-1,1)$ & -0.0048 & 0.7334 \\
\hline$(-1,3)$ & -0.0057 & 0.5745 \\
\hline$(-3,3)$ & 0.0083 & 0.5844 \\
\hline $\begin{array}{c}110 / 07 / 2013 \\
\text { EC proposes SRM for the Banking Union } \\
\end{array}$ & CAR & P-value \\
\hline$(-1,0)$ & -0.0106 & 0.2511 \\
\hline$(-1,1)$ & -0.0100 & 0.3270 \\
\hline$(-1,3)$ & -0.0067 & 0.9331 \\
\hline$(-3,3)$ & -0.0084 & 0.9644 \\
\hline $\begin{array}{l}15 / 04 / 2014 \\
\text { Formal adoption by the European Parliament }\end{array}$ & CAR & P-value \\
\hline$(-1,0)$ & -0.0195 & 0.0077 \\
\hline$(-1,1)$ & -0.0200 & 0.0157 \\
\hline$(-1,3)$ & -0.0204 & 0.0152 \\
\hline$(-3,3)$ & -0.0260 & 0.0230 \\
\hline
\end{tabular}




\section{Table 2. Determinants of CARs}

This table illustrates empirical results from the regression models examining the determinants of CARs around the implementation of the new bail-in regime. Data are collected from Datastream and BankScope databases. Robust standard errors are in parentheses. ${ }^{* *}, * *, *$ denote statistically significance at the $1 \%, 5 \%$, and $10 \%$ levels, respectively.

\begin{tabular}{lcccc}
\hline & $(1)$ & $(2)$ & $(3)$ & $(4)$ \\
& car13 & car10 & car33 & car11 \\
\hline \multirow{2}{*}{ EUR } & & & & \\
& $-0.00960^{* *}$ & $-0.00717 * *$ & $-0.0184 * * *$ & -0.00422 \\
SIZE & $(0.00463)$ & $(0.00356)$ & $(0.00577)$ & $(0.00520)$ \\
& $-0.00342^{* * *}$ & $-0.00250^{*}$ & -0.000994 & $-0.00291^{* *}$ \\
AID & $(0.00131)$ & $(0.00128)$ & $(0.00180)$ & $(0.00140)$ \\
& $-0.0122^{* *}$ & $-0.00923 *$ & $-0.0331 * * *$ & -0.00510 \\
INTB & $(0.00598)$ & $(0.00494)$ & $(0.0116)$ & $(0.00710)$ \\
& $-0.000523^{* *}$ & 0.000113 & $-0.000688^{* *}$ & -0.000193 \\
CIR & $(0.000201)$ & $(0.000434)$ & $(0.000336)$ & $(0.000302)$ \\
CAP & -0.0171 & -0.0125 & -0.00889 & -0.0130 \\
& $(0.0131)$ & $(0.0151)$ & $(0.0175)$ & $(0.0226)$ \\
RWA & 0.0328 & 0.0489 & 0.119 & -0.00593 \\
ANN & $(0.0594)$ & $(0.0542)$ & $(0.0869)$ & $(0.0624)$ \\
& $-0.0412^{* *}$ & $-0.0344 * *$ & $-0.0493 * *$ & $-0.0348 *$ \\
Constant & $(0.0164)$ & $(0.0170)$ & $(0.0215)$ & $(0.0177)$ \\
& $0.0118^{* * *}$ & -0.00461 & $0.0119 * *$ & 0.00328 \\
Observations & $(0.00417)$ & $(0.00352)$ & $(0.00542)$ & $(0.00416)$ \\
R-squared & $0.0679 *$ & 0.0543 & 0.0145 & 0.0628 \\
& $(0.0379)$ & $(0.0375)$ & $(0.0535)$ & $(0.0437)$ \\
& & & & 199 \\
& 199 & 199 & 199 & 0.063 \\
\hline
\end{tabular}




\section{Acknowledgements}

We would like to thank the participants of the 2017 IRMC, 2017 LAPE Bank Colloquium for Junior Researchers, and 2017 FINEST Conferences for their useful comments. Special thanks to Nicola Cetorelli, Robert De Young, George Pennacchi, Iftekhar Hasan, John Kose, and Sebastian Schich. We alone are responsible for any remaining errors. 


\section{References}

Avgouleas, E., Goodhart, C., 2015. Critical reflections on bank bail-ins. Journal of Financial Regulation. 1, 3-29.

Benczur, P., Cannas, G., Cariboni, J., Di Girolamo, F., Maccaferri, S., Giudici, M.P., 2017. Evaluating the effectiveness of the new EU bank regulatory framework: A farewell to bail-out? Journal of Financial Stability. 33, 207-223.

Caprio, G., Honohan, P., 2015. Banking crises, in: Berger, A., Molyneux, P., Wilson, J.O.S. (Eds.), Oxford Handbook of Banking. Oxford University Press.

Chiorazzo, V., D'Apice, V., DeYoung, R., Morelli, P., 2018. Is the traditional banking model a survivor? Journal of Banking \& Finance. 97, 238-256.

Fiordelisi, F., Galloppo, G., Ricci, O., 2014. The effect of monetary policy interventions on interbank markets, equity indices and G-SIFIs during financial crisis. Journal of Financial Stability. 11, 49-61.

Kolari, J.W., Pynnönen, S., 2010. Event study testing with cross-sectional correlation of abnormal returns. The Review of Financial Studies. 23, 3996-4025.

Mattana, P., Petroni, F., Rossi, S.P.S., 2015. A test for the too-big-to-fail hypothesis for European banks during the financial crisis. Applied Economics. 47, 319-332.

Papanikolaou, N.I., 2018. A dual early warning model of bank distress. Economics Letters. 162, $127-130$.

Schäfer, A., Schnabel, I., Weder, B., 2016. Bail-in expectations for European banks: Actions speak louder than Words. CEPR Discussion Paper No. DP11061.

Schoenmaker, D., 2014. On the need for a fiscal backstop to the banking system. Duisenberg School of Finance Policy Paper Series No. 44, 42-54. 